\title{
Streptomyces cavourensis sp. nov. (nom. rev.) and Streptomyces cavourensis subsp. washingtonensis subsp. nov., a Chromomycin-Producing Subspecies
}

\author{
JERRY D. SKARBEK ${ }^{1}$ AND LYNN R. BRADY ${ }^{2}$ \\ Department of Pharmacognosy, School of Pharmacy, University of Maryland, Baltimore, Maryland 21201, ${ }^{1}$ \\ and Department of Pharmaceutical Sciences, School of Pharmacy, University of Washington, Seattle, \\ Washington $98195^{2}$
}

\begin{abstract}
A Streptomyces strain, AUW-83, isolated as a contaminant in a marine fungal culture and previously reported to produce the chromomycin antibiotics, was taxonomically evaluated by direct comparison with strains selected from those species which were previously studied and reported by collaborators of the International Streptomyces Project and with additional strains. Strain AUW-83 was found to resemble strain 829 of the flavensomycin-producing species, Streptomyces cavourensis Giolitti 1958 (which name was not effectively published, according to Rule 25b of the Bacteriological Code, 1976 revision), more closely than strain 689 of the xanthicin-producing species, S. xanthochromogenus (sic) Arishima, Sakamoto, and Sato 1956. Two additional strains of the "griseus" series-Illinois 205-2 and Illinois 205-2M-reputed to produce flavensomycin were observed to be phenotypically very similar both to strain 829 and to strain AUW-83. These four strains appear to belong to one and the same species, for which we propose the name Streptomyces cavourensis. Because the name $S$. cavourensis was not effectively published by Giolitti, it is available for use (as a revived name [nom. rev.]) for the same or for a different species. To avoid confusion and chaos, we have elected to use the name $S$. cavourensis for the same organism to which Giolitti originally applied the name. However, under the circumstances, the name $S$. cavourensis is to be attributed to the present authors, namely Skarbek and Brady, not to Giolitti. The production of structurally unrelated antibiotics is regarded by us as a major indication for subspecific differentiation of strain AUW-83 from the flavensomycin-producing strains of $S$. cavourensis, and so we place strain AUW-83 in a separate subspecies, for which we propose the name Streptomyces cavourensis subsp. washingtonensis subsp. nov. Strain 829 of Giolitti (= ATCC $14889=$ CBS $669.69=$ NRRL 2740) is designated the type strain of $S$. cavourensis, and strain AUW-83 (= ATCC 27732 $=$ NRRL B-8030) is designated the type strain of S. cavourensis subsp. washing. tonensis. The valid publication of this subspecies name automatically creates the publication of the name of the type subspecies-S. cavourensis subsp. cavourensis Skarbek and Brady-the nomenclatural type of which is strain 829 .
\end{abstract}

A previously undescribed streptomycete, isolated as a contaminant in a marine fungal culture, was found to produce chromomycin $\mathrm{A}_{3}$ (24), a member of the aureolic acid group of Actinomycetales antibiotics (2). Chromomycin $\mathrm{A}_{3}$ exhibits antitumor activity and is currently under clinical evaluation by the National Cancer Institute of the National Institutes of Health $(12,15)$. Key taxonomic features of the streptomycete, which was given the strain designation AUW-83, were ascertained and then compared with those in the literature for organisms alleged to produce antibiotics belonging to the aureolic acid group; 15 strains of organisms alleged to produce antibiotics of the aureolic acid group were obtained for direct taxonomic comparison with strain AUW-83. Strain AUW-83 was found to be easily distinguishable from this group of organisms on the basis of melanin reaction, spore chain morphology, color of sporulating culture, and utilization of carbon sources. Details of these considerations are presented in the accompanying paper (25).

Further comparisons of these key features were made with the published descriptions of over 450 strains evaluated by the International Streptomyces Project (ISP) (20-23). The new isolate was found to resemble strain 829 of Streptomyces cavourensis Giolitti 1958 (7, 22; G. Giolitti and R. Craveri, Belgian patent 560,930, 18 March 1958 [18]; an ineffectively published name according to Rule $25 \mathrm{~b}$ of the Bacteriolog- 
ical Code, 1976 revision [13]) and strain 689 of S. xanthochromogenus (sic) Arishima, Sakamoto, and Sato $(1,20)$ in primary-group characters (9) and to differ from these organisms in the utilization of no more than one of the standard carbon compounds. This report concerns a direct taxonomic comparison of strain AUW. 83 with strains 829 and 689 and with two additional strains not studied by the collaborators of the ISP: Illinois 205-2 and Illinois 205-2M.

(This manuscript was abstracted in part from a dissertation submitted to the Graduate School of the University of Washington by J. D. Skarbek in partial fulfillment of the requirements for the degree of Doctor of Philosophy.)

\section{MATERIALS AND METHODS}

Bacterial strains. Strain AUW-83 (Actinomycetales University of Washington-83) was found as a contaminant in a marine fungal culture received from Gilbert C. Hughes III, marine mycologist at the University of British Columbia, Vancouver, Canada. Cultures of S. cavourensis Giolitti strain 829 and S. xanthochromogenes strain 689 (type strain) were received from the Centraalbureau voor Schimmelcultures, Baarn, Netherlands under the numbers 669.69 and 571.68, respectively. Strain 829 was reported to produce flavensomycin, an antibiotic with fungicidal and insecticidal activities $(6,7)$. It was of interest, therefore, to examine two other alleged flavensomycin-producing strains (5) belonging to the "griseus" series-Illinois 205-2 and Illinois 205-2M-which were acquired from the Northern Regional Research Center, Peoria, Ill., under the numbers B-3001 and B3002 , respectively. All strains were maintained in the sporulating state on Difco ISP medium 2.

ISP methods. Recommended procedures were employed for the determinations of spore chain morphology, spore characteristics, aerial mass color, color of substrate mycelium and soluble pigments, melanoid pigmentation, and carbon utilization (19). ISP media $1,2,3,4,5,6,7$, and 9 were obtained from Difco Laboratories.

Additional materials and methods. Growth characteristics on medium 7 (glycerol-calcium malate agar) and medium 42 (tyrosine-yeast extract agar) of Waksman (27) were determined. Attention was focused on the aerial mass color, the solubilization of malate in medium 7 , and the formation of melanoid pigments in medium 42. A spore inoculum was employed.

Dextran (clinical grade, molecular weight 60,000 to 90,000 , Nutritional Biochemicals Corp.) was employed in an assimilation test in a manner similar to that used in the standard test for determining utilization of sole carbon sources. The dextran was sterilized by overlaying it with reagent grade diethyl ether, and the ether was allowed to evaporate prior to incorporation of the dextran into the cooled, melted, carbon utilization agar.

Arylsulfatase activity was determined in petri plates (15 by $100 \mathrm{~mm}$ ) using Wayne sulfatase agar (BBL). The agar plates were inoculated by streaking once across the middle with a loopful of a heavy spore suspension in sterilized, distilled water. Cultures were incubated at $28^{\circ} \mathrm{C}$ for 10 days and then flooded with $10 \mathrm{ml}$ of $1 \mathrm{M}$ sodium carbonate solution. Production of a pink to red color was taken to indicate the presence of free phenolphthalein liberated by the enzymatic attack on the substrate, tripotassium phenolphthalein sulfate.

The tolerance of organisms to selected heavy metals was assessed in a basal medium with the following formula: glucose (BBL), 1.0\%; peptone (Difco), $0.5 \%$; yeast extract (BBL), $0.1 \%$; sodium chloride, $0.5 \%$; distilled water, with adjustment of $\mathrm{pH}$ to 7.6 with dilute $\mathrm{NaOH}$ prior to autoclaving; agar (BBL), $1.5 \%$. Salts of heavy metals $\left(\mathrm{ZnCl}_{2} ; \mathrm{CuSO}_{4} \cdot 5 \mathrm{H}_{2} \mathrm{O} ; \mathrm{CoCl}_{2} \cdot 6 \mathrm{H}_{2} \mathrm{O}\right)$ were sterilized separately by filtration (Falcon 7103 filters) and then incorporated into the cooled, melted basal agar at $50 \mu \mathrm{g} / \mathrm{ml}$ based on the heavy-metal content. The test plates were inoculated with a spore suspension in the same manner as described for the ISP standard procedure for inoculating plates for morphological studies (19). The cultures were incubated at $28^{\circ} \mathrm{C}$ and observed over a period of 24 days. Growth of the organisms on the heavy-metal agars was compared to growth on the basal medium alone.

The susceptibility of the organisms to selected antibiotics was determined with sensitivity test agar (BBL) and a single high-potency disk (BBL; penicillin, $10 \mathrm{U}$; erythromycin, $15 \mu \mathrm{g}$ ). Chromomycin $\mathrm{A}_{3}$, isolated from strain AUW-83 (24), was also employed, but at a strength of $1.0 \mu \mathrm{g}$ per disk (Schleicher \& Schuell, $740-\mathrm{E}, 12.7 \mathrm{~mm}$ ). Spores from either one-half of a slant culture or from a full slant culture were harvested in $5 \mathrm{ml}$ of sterilized, distilled water, incorporated into $100 \mathrm{ml}$ of the cooled, melted test agar, and dispensed into three petri plates ( 15 by $100 \mathrm{~mm}$ ). Agar plates of Staphylococcus aureus NRRL B-313 and Escherichia coli ATCC 10536 were similarly prepared and were used as controls both for disk potency and for determination of relative resistance of the study organisms to the antibiotics employed. The control strains were cultivated on a rotary shaker in $50 \mathrm{ml}$ of Trypticase soy broth (BBL) for $24 \mathrm{~h}$ at $28^{\circ} \mathrm{C}$; a $0.1 \% \mathrm{vol} / \mathrm{vol}$ inoculum concentration was utilized. After application of the antibiotic-impregnated disks to the solidified media, the test plates were incubated at $28^{\circ} \mathrm{C}$ for 24 to $48 \mathrm{~h}$. Diameters of the zones of inhibition were then recorded.

The antibiotic activities of the study strains were evaluated in a medium similar to that used by Chacko and Gottlieb for study of strains Illinois 205-2 and Illinois 205-2M (5): glucose (BBL), 1.0\%; yeast extract (Amber BYF 300), $0.05 \%$; peptone (Difco), $0.5 \%$; molasses (Grandma's brand label), $2.0 \%$; distilled water, pH 6.1 without adjustment either prior to or after autoclaving. Aqueous spore suspensions were used to inoculate $50 \mathrm{ml}$ of the molasses medium contained in 250-ml, cotton-plugged Erlenmeyer flasks. The flasks were incubated at $28^{\circ} \mathrm{C}$ for $96 \mathrm{~h}$ on a rotary shaker. Broth activity was determined against Staphylococcus aureus NRRL B-313, E. coli ATCC 10536, and Saccharomyces cerevisiae NRRL Y-567 using saturated paper disks (Schleicher \& Schuell, $12.5 \mathrm{~mm}$ ) and the bioassay conditions as described above for antibiotic susceptibility testing. 


\section{RESULTS}

Spore chain morphology. Strain AUW-83 exhibited straight to flexuous chains of spores (Fig. 1) on all standard media and thus belongs to the section Rectiflexibiles of the genus Streptomyces. Strains Illinois 205-2 and Illinois 205$2 \mathrm{M}$ were found to belong to section $R F$, as were strain 829 and strain 689 . Light micrographs of sporulating aerial mycelia of strain 829 and strain 689 have been previously published by ISP collaborators $(20,22)$.

Spore characteristics. The spore type of strain AUW-83 was found to be smooth (Fig. 2). Strains Illinois $205-2$ and Illinois $205-2 \mathrm{M}$ exhibited smooth spores (yeast-malt extract agar), as did strain 829 and strain 689 . Electron micrographs illustrating the spore characteristics of strain 829 and strain 689 were previously published by ISP collaborators $(20,22)$.

Color determinations. The mass color of mature, sporulating aerial surface growth of cultures of each strain on standard media and on glycerol-calcium malate agar is presented in Table 1. Malate was moderately solubilized by all of the strains except strain 689 , which gave a weak response.

No distinctive pigments other than yellowbrown were found in the reverse mycelium (i.e., reverse side of colony) of cultures of all of the strains studied. Diffusible, soluble pigments other than brown or black were found only with strain 689 grown on the standard media. This yellow, soluble pigment was not a $\mathrm{pH}$ indicator.

Observations on the production of melanoid pigments by the strains on standard media and on Waksman medium 42 are presented in Table 2. All cultures, except that of strain Illinois 205$2 \mathrm{M}$, were found to produce melanoid pigments on at least three of the four media which were utilized. Strain Illinois 205-2M failed to produce melanoid pigments on any of the melanin formation media employed.

Carbon utilization. The results of the tests for utilization of carbon sources for growth by all strains are given in Table 3. Despite the use of positive (glucose) and negative (no carbon source) controls, it was difficult to assess readings in a limited number of cases, such as arabinose utilization by strains 829 and Illinois 205-

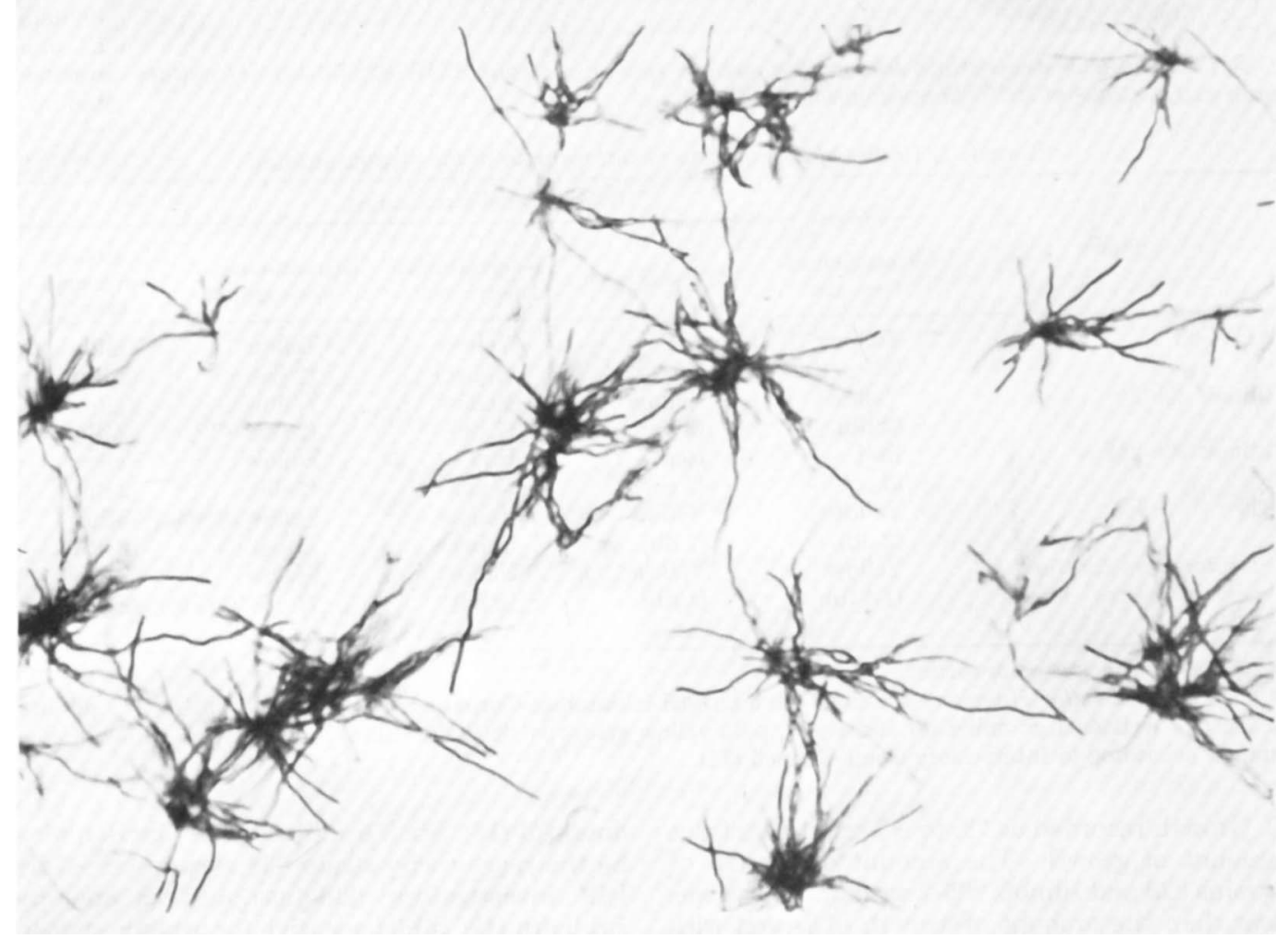

FIG. 1. Light micrograph of sporulating aerial mycelium of strain AUW-83. Rectiflexibiles morphology on glycerol-asparagine agar, $28^{\circ} \mathrm{C}$ for 14 days. Magnification, $\times 655$. 


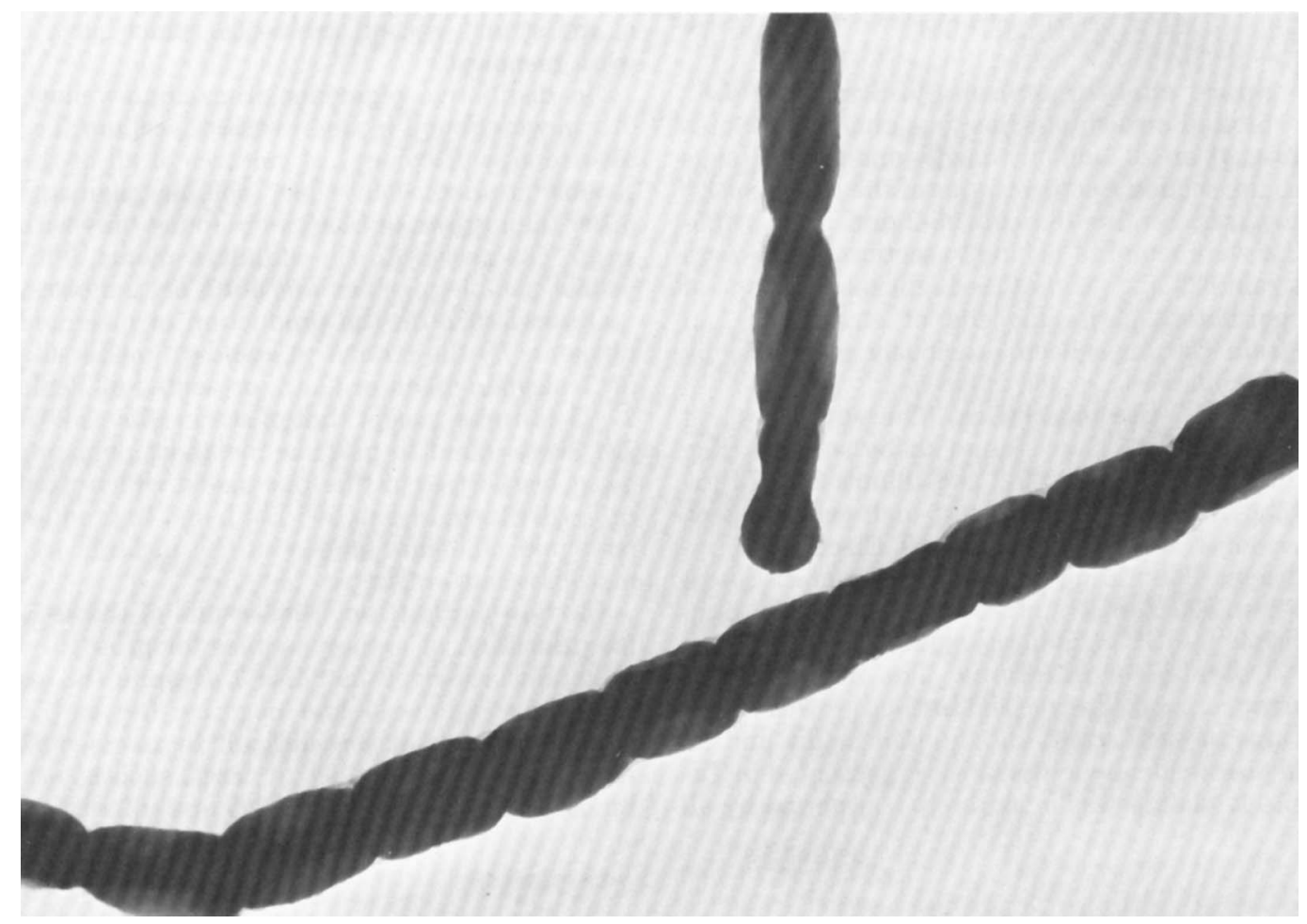

FiG. 2. Electron micrograph illustrating smooth spores of strain AUW.83; 14-day-old culture on yeastmalt extract agar at $28^{\circ} \mathrm{C}$. Magnification, $\times 20,300$.

TABLE 1. Colors of sporulating aerial mycelia of the strains studied

\begin{tabular}{|c|c|c|c|c|c|}
\hline \multirow[b]{2}{*}{ Strain } & \multicolumn{5}{|c|}{ Color of aerial mycelium on: } \\
\hline & $\begin{array}{l}\text { Yeast-malt ex- } \\
\text { tract agar }\end{array}$ & Oatmeal agar & $\begin{array}{l}\text { Inorganic salts- } \\
\text { starch agar }\end{array}$ & $\begin{array}{l}\text { Glycerol-aspar- } \\
\text { agine agar }\end{array}$ & $\begin{array}{l}\text { Glycerol-cal- } \\
\text { cium malate } \\
\text { agar } \\
\end{array}$ \\
\hline AUW-83 & $\begin{array}{l}\text { Yellow }^{a} \\
(11 / 2 \text { ec })^{b}\end{array}$ & $\begin{array}{l}\text { Yellow } \\
\left(1^{1 / 2} \text { ec) }\right.\end{array}$ & $\begin{array}{l}\text { Yellow } \\
\left(1^{1 / 2} \text { ec }\right)\end{array}$ & $\begin{array}{l}\text { Yellow } \\
\text { ( } 2 \text { ba) }\end{array}$ & $\begin{array}{l}\text { Yellow } \\
(2 \mathrm{db})\end{array}$ \\
\hline Illinois $205-2$ & $\begin{array}{l}\text { Yellow } \\
(2 \mathrm{db})\end{array}$ & $\begin{array}{l}\text { Yellow } \\
(2 \text { ba) }\end{array}$ & $\begin{array}{l}\text { Yellow } \\
\text { ( } 2 \text { ba) }\end{array}$ & $\begin{array}{l}\text { Yellow } \\
(2 \mathrm{db})\end{array}$ & $\begin{array}{l}\text { Yellow } \\
(2 \mathrm{db})\end{array}$ \\
\hline Illinois $205-2 \mathrm{M}$ & $\begin{array}{l}\text { Red } \\
(3 \mathrm{ec})\end{array}$ & $\begin{array}{l}\text { Red } \\
(3 \mathrm{ec})\end{array}$ & $\begin{array}{l}\text { Red } \\
(3 \mathrm{ec})\end{array}$ & $\begin{array}{l}\text { Yellow } \\
(2 \mathrm{db})\end{array}$ & $\begin{array}{l}\text { Yellow } \\
(2 \mathrm{db})\end{array}$ \\
\hline 829 & $\begin{array}{l}\text { Yellow } \\
(2 \mathrm{db})\end{array}$ & $\begin{array}{l}\text { Yellow } \\
(2 \mathrm{db})\end{array}$ & $\begin{array}{l}\text { Yellow } \\
(2 \mathrm{ba})\end{array}$ & $\begin{array}{l}\text { Yellow } \\
\text { ( } 2 \text { ba) }\end{array}$ & $\begin{array}{l}\text { Yellow } \\
(2 \mathrm{db})\end{array}$ \\
\hline $\begin{array}{l}\text { Streptomyces xantho- } \\
\text { chromogenes strain } \\
689\end{array}$ & $\begin{array}{l}\text { Yellow } \\
\left(1^{1 / 2} \mathrm{fb}\right)\end{array}$ & $\begin{array}{l}\text { Yellow } \\
\text { (1 db) }\end{array}$ & $\begin{array}{l}\text { Yellow } \\
(2 \text { ba) }\end{array}$ & $\begin{array}{l}\text { Yellow } \\
(1 \mathrm{cb})\end{array}$ & $\begin{array}{l}\text { Yellow } \\
(2 \mathrm{db})\end{array}$ \\
\hline
\end{tabular}

${ }^{\alpha}$ Tresner-Backus color series.

b Tabs from Color Harmony Manual, 4th ed, 1958 (Container Corporation of America, Chicago); $2 \mathrm{db}$ and

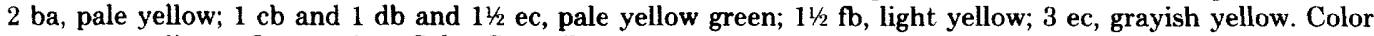
names according to Intersociety Color Council (11).

2. Growth recorded as " \pm to + " refers to a trace amount of growth. The amount of growth of strains 829 and Illinois $205-2$ with arabinose was less than the amount of growth observed with dextran, but it certainly was better than that which a reading of " \pm " indicates-utilization doubtful (19). Such a subjective distinction may be the reason why strain 829 was described by ISP investigators (22) as positive and by Pridham $(17,18)$ as negative for arabinose utilization. Strain 689 differed from all of the other strains studied by producing a trace amount of 
growth on basal medium supplemented with xylose and raffinose and by being unable to assimilate dextran.

Arylsulfatase activity. Only strain 689 gave a positive reaction for arylsulfatase activity. In 1958, Wayne and co-workers (29) reported on a study of arylsulfatase activity by mycobacteria and aerobic Actinomycetales. Eight streptomycetes, without mention of species names or sources, were found to give a negative reaction after 14 days of incubation. The report given here is an indication that some streptomycetes are capable of exhibiting arylsulfatase activity.

Tolerance of the streptomycetes studied to heavy metals. The cultural characteristics of the study strains on heavy-metal agars relative to the control basal medium are presented in Table 4. The mineral metabolism of streptomycetes has usually been approached from the standpoint of effects on antibiotic production, and toxicity levels of heavy metals have been defined in limited cases (26). The data reported

TABLE 2. Production of melanoid pigments by the strains studied

\begin{tabular}{|c|c|c|c|c|}
\hline \multirow{3}{*}{ Strain } & \multicolumn{4}{|c|}{$\begin{array}{c}\text { Production of melanoid pigments } \\
\text { on: }\end{array}$} \\
\hline & \multicolumn{3}{|c|}{ ISP medium } & \multirow{2}{*}{$\begin{array}{l}\text { Waksman } \\
\text { medium } 42\end{array}$} \\
\hline & No. 1 & No. 6 & No. 7 & \\
\hline AUW-83 & + & + & $+^{a}$ & + \\
\hline Illinois 205-2 & + & + & + & + \\
\hline Illinois 205-2M & - & - & - & - \\
\hline 829 & + & + & $-b$ & + \\
\hline $\begin{array}{l}\text { Streptomyces xan- } \\
\text { thochromogenes } \\
\text { strain } 689\end{array}$ & + & + & + & + \\
\hline
\end{tabular}

${ }^{a}$ Definite browning was observed beneath sporulating aerial mycelium which had developed at the top of the test slants; only trace browning occurred where growth was present but no aerial mycelium had appeared.

${ }^{b}$ Only trace browning was observed. in this study may indicate that there exists a differential tolerance among streptomycetes toward heavy metals. Strain AUW-83 differed from all of the other strains in that it produced a soluble, dark brown pigment, modified by graygreen, after 10 days of incubation on the basal agar supplemented with zinc. Little soluble pigment, except for a slight yellow-brown exhibited by strain 689 , was observed with the remaining strains on the zinc agar.

Susceptibility to antibiotics. The responses of the streptomycetes studied to selected antibiotics are presented in Table 5. Resistance to antibiotics is a relative term, and no standardized procedure exists for determining susceptibilities of streptomycetes to antibiotics. The method reported in this investigation is not claimed to be either ideal or without limitation, but it utilized a very necessary component which should be inherent in any such procedure, namely, relative responses of quality control organisms. Quality control cultures permit control of the accuracy of test procedures and are included in the standardized procedures of the Kirby-Bauer method for antibiotic susceptibility testing recently adopted by the National Committee for Clinical Laboratory Standards (16). Staphylococcus aureus ATCC 25923, E. coli ATCC 25922, and Pseudomonas aeruginosa ATCC 27853 are employed in this clinical laboratory procedure.

If Staphylococcus aureus NRRL B-313 is considered to be susceptible to penicillin, chromomycin $\mathrm{A}_{3}$, and erythromycin, and $E$. coli ATCC 10536 is considered to be resistant, then the data for the streptomycetes can be assessed on a relative basis. Accordingly, both strain similarities and differences were displayed in these data.

Antibiotic activity. Results from a limited testing for antibiotic activities are given in Table 6. Strain 829 displayed no detectable activity against any of the three test organisms. Strain AUW-83 exhibited a pattern consistent with its

TABLE 3. Utilization of carbon sources for growth by the strains studied

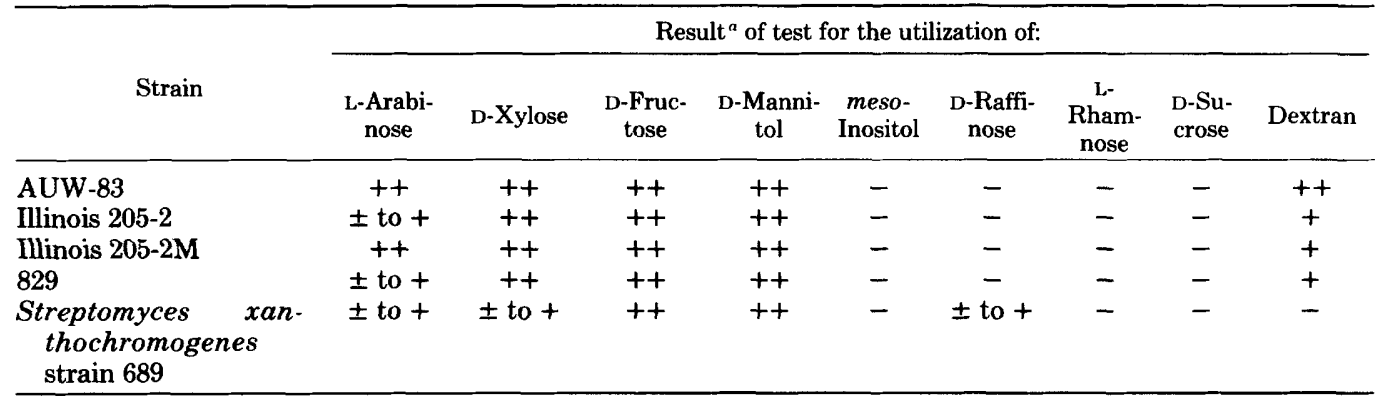

a Symbols: - , negative response; \pm , doubtful response; + , more growth than on carbon control but less than on glucose; ++ , positive response equal to the amount of growth on glucose. 
TABLE 4. Tolerance of the strains studied to selected heavy metals

\begin{tabular}{|c|c|c|c|c|}
\hline \multirow{3}{*}{ Strain } & \multicolumn{4}{|c|}{ Growth on: } \\
\hline & \multirow{2}{*}{ Basal agar } & \multicolumn{3}{|c|}{ Basal agar plus:“ } \\
\hline & & $\mathrm{Zn}^{2+}$ & $\mathrm{Cu}^{2+}$ & $\mathrm{Co}^{2+}$ \\
\hline AUW-83 & $\begin{array}{l}\text { Good growth and } \\
\text { sporulation; } \\
\text { brown soluble } \\
\text { pigment }\end{array}$ & $\begin{array}{l}\text { Good growth; no } \\
\text { aerial mycelium; } \\
\text { brown soluble } \\
\text { pigment modified } \\
\text { by gray-green }\end{array}$ & $\begin{array}{l}\text { Similar to that of } \\
\text { control; brown- } \\
\text { black soluble } \\
\text { pigment }\end{array}$ & $\begin{array}{l}\text { Only two to three } \\
\text { isolated sporu- } \\
\text { lating colonies; } \\
\text { brown-black sol- } \\
\text { uble pigment }\end{array}$ \\
\hline lllinois $205-2$ & $\begin{array}{l}\text { Good growth and } \\
\text { sporulation; } \\
\text { brown soluble } \\
\text { pigment }\end{array}$ & $\begin{array}{l}\text { Moderate growth; } \\
\text { no aerial myce- } \\
\text { lium; little solu- } \\
\text { ble pigment }\end{array}$ & $\begin{array}{l}\text { Moderate growth } \\
\text { and sporulation; } \\
\text { brown-black sol- } \\
\text { uble pigment }\end{array}$ & $\begin{array}{l}\text { Moderate growth } \\
\text { and sporulation; } \\
\text { brown-black sol- } \\
\text { uble pigment }\end{array}$ \\
\hline Illinois $205-2 \mathrm{M}$ & $\begin{array}{l}\text { Good growth and } \\
\text { sporulation; lit- } \\
\text { tle, if any soluble } \\
\text { pigment }\end{array}$ & $\begin{array}{l}\text { Moderate growth; } \\
\text { no aerial myce- } \\
\text { lium; little solu- } \\
\text { ble pigment }\end{array}$ & $\begin{array}{l}\text { Similar to that of } \\
\text { control; little sol- } \\
\text { uble pigment }\end{array}$ & No growth \\
\hline 829 & $\begin{array}{l}\text { Good growth and } \\
\text { sporulation; } \\
\text { brown soluble } \\
\text { pigment }\end{array}$ & $\begin{array}{l}\text { Moderate growth; } \\
\text { no aerial myce- } \\
\text { lium; little solu- } \\
\text { ble pigment }\end{array}$ & $\begin{array}{l}\text { Moderate growth } \\
\text { and sporulation; } \\
\text { brown-black sol- } \\
\text { uble pigment }\end{array}$ & $\begin{array}{l}\text { Moderate growth } \\
\text { and sporulation; } \\
\text { brown-black sol- } \\
\text { uble pigment }\end{array}$ \\
\hline $\begin{array}{l}\text { Streptomyces xan- } \\
\text { thochromogenes } \\
\text { strain } 689\end{array}$ & $\begin{array}{l}\text { Good growth and } \\
\text { sporulation; } \\
\text { brown soluble } \\
\text { pigment modified } \\
\text { by yellow }\end{array}$ & $\begin{array}{l}\text { Moderate growth } \\
\text { and sporulation; } \\
\text { brown soluble } \\
\text { pigment modified } \\
\text { by yellow }\end{array}$ & $\begin{array}{l}\text { Very weak, stunted } \\
\text { growth }\end{array}$ & No growth \\
\hline
\end{tabular}

a Supplemented at $50 \mu \mathrm{g} / \mathrm{ml}$ based on the heavy-metal content.

TABLE 5. Comparison of the strains studied to Staphylococcus aureus NRRL B-313 and Escherichia coli ATCC 10536 with respect to susceptibility to selected antibiotics

\begin{tabular}{|c|c|c|c|}
\hline \multirow{2}{*}{ Strain } & \multicolumn{3}{|c|}{$\begin{array}{l}\text { Diam }(\mathrm{mm}) \text { of zone of inhibition } \\
\text { produced by: }\end{array}$} \\
\hline & Penicillin & $\begin{array}{l}\text { Erythro- } \\
\text { mycin }\end{array}$ & $\begin{array}{l}\text { Chromo- } \\
\text { mycin A.s }\end{array}$ \\
\hline AUW-83 & 14 & 12 & $\mathbf{N}^{a}$ \\
\hline Illinois $205-2$ & 14 & 12 & 24 \\
\hline Illinois $205-2 \mathrm{M}$ & 14 & 12 & 24 \\
\hline 829 & 14 & 12 & 24 \\
\hline $\begin{array}{l}\text { Streptomyces xan } \\
\text { thochromogenes } \\
\text { strain } 689\end{array}$ & $\mathbf{N}$ & 32 & $N$ \\
\hline $\begin{array}{l}\text { Staphylococcus au- } \\
\text { reus NRRL B-313 }\end{array}$ & 36 & 30 & 20 \\
\hline $\begin{array}{ll}\text { Escherichia } & \text { coli } \\
\text { ATCC } 10536 & \\
\end{array}$ & 12 & 14 & $\mathrm{~N}$ \\
\hline
\end{tabular}

known chromomycin-producing capacity (24), exhibiting antagonism of Staphylococcus aureus NRRL B-313 but not of $E$. coli ATCC 10536 or Saccharomyces cerevisiae NRRL Y-567. Strains Illinois 205-2 and Illinois 205-2M presented an antibiotic activity pattern consistent with their reported ability to produce flavensomycin and humidin, antibiotics possessing antifungal but little or no antibacterial activity $(5,6)$. Strain
TABLE 6. Antibiotic activities of the strains studied against selected test organisms

\begin{tabular}{lccc}
\hline \multicolumn{4}{c}{ against selected test organisms } \\
\cline { 2 - 4 } \multicolumn{1}{c}{ Strain } & $\begin{array}{c}\text { Diam (mm) of zone of inhibition against: } \\
\text { coccus au- } \\
\text { reus NRRL } \\
\text { B-313 }\end{array}$ & $\begin{array}{c}\text { Esche- } \\
\text { richia coli } \\
\text { ATCC }\end{array}$ & $\begin{array}{c}\text { Saccharo- } \\
\text { myces cere- } \\
\text { visiae } \\
\text { NRRL Y- } \\
10536\end{array}$ \\
\hline AUW-83 & 22 & $\mathrm{~N}^{\prime \prime}$ & $\mathrm{N67}$ \\
Illinois 205-2 & $\mathrm{N}$ & $\mathrm{N}$ & 22 \\
Illinois 205-2M & $\mathrm{N}$ & $\mathrm{N}$ & 22 \\
829 & $\mathrm{~N}$ & $\mathrm{~N}$ & $\mathrm{~N}$ \\
Streptomyces & 20 & 16 & 16 \\
$\quad$ xantho- & & & \\
chromogenes & & & \\
strain 689 & & & \\
\hline
\end{tabular}

${ }^{a} \mathrm{~N}$, No zone of inhibition.

689 has been reported (28) to produce the antibiotic xanthicin, which was found to be weakly active against certain fungi and gram-positive bacteria. The data in this study indicate that strain 689 has the capacity to antagonize not only fungi and gram-positive bacteria but also gram-negative bacteria.

\section{DISCUSSION}

Gottlieb and Shirling (9) and Hütter (10) have suggested a primary group of four characteristics (sporophore morphology, spore surface, color of 
TABle 8. Differentiation of Pseudomonas pseudoflava from Pseudomonas flava

\begin{tabular}{|c|c|c|}
\hline Distinguishing character & P. pseudoflava & P. flava \\
\hline \multicolumn{3}{|l|}{ Growth on: } \\
\hline Xylose $\ldots \ldots \ldots \ldots \ldots \ldots$ & + & - \\
\hline$p$-Hydroxybenzoate & + & - \\
\hline Phenol . . . . . . & + & - \\
\hline L-Lysine $\ldots \ldots$ & + & - \\
\hline L-Leucine $\ldots \ldots \ldots \ldots \ldots$ & + & - \\
\hline L-Isoleucine $\ldots \ldots \ldots \ldots$ & + & - \\
\hline L-Tryptophan $\ldots \ldots \ldots \ldots$ & + & - \\
\hline L-Asparagine $\ldots \ldots \ldots \ldots \ldots$ & + & - \\
\hline L-Phenylalanine & + & - \\
\hline L-Tyrosine $\ldots \ldots \ldots \ldots \ldots \ldots$ & + & - \\
\hline \multicolumn{3}{|l|}{ Cross-agglutination with: } \\
\hline GAl antiserum $\ldots \ldots \ldots \ldots \ldots$ & + & - \\
\hline GA2 antiserum $\ldots \ldots \ldots \ldots$ & + & - \\
\hline GA3 antiserum $\ldots \ldots \ldots \ldots$ & + & - \\
\hline Denitrification & + & - \\
\hline Tolerance to $20 \% \mathrm{O}_{2}$ & + & - \\
\hline Temperature optimum & $35-38^{\circ} \mathrm{C}$ & $30^{\circ} \mathrm{C}$ \\
\hline $\begin{array}{l}\text { Absorption maxima of pigments (in } \\
\text { acetone) }\end{array}$ & $\begin{array}{lr}\text { "Neutral" } & (400) 423446 \\
\text { "Acidic" } & 327(400) 423446\end{array}$ & $\begin{array}{ll}\text { "Neutral" } & (415) 442(468)^{a} \\
\text { "Acidic" } & (415) 440(465)^{a}\end{array}$ \\
\hline DNA-DNA homology $\ldots \ldots \ldots \ldots$ & $\begin{array}{l}\text { High-interstrain DNA-DNA ho- } \\
\text { mology }(85-100 \%)\end{array}$ & $\begin{array}{l}\text { Only moderate DNA-DNA ho- } \\
\text { mology to the strains of } P \text {. pseu- } \\
\text { doflava (52-68\%) }\end{array}$ \\
\hline
\end{tabular}

${ }^{a}$ Data from D. Davis (Ph.D. thesis).

idase positive; possesses cytochromes of the $a, b$, and $c$ types.

The temperature for optimal growth is between 35 and $38^{\circ} \mathrm{C}$. The maximum temperature for growth is between 40 and $41^{\circ} \mathrm{C}$.

Some strains are susceptible to temperate phages, the host range of which is very restrictive. $\mathrm{G}+\mathrm{C}$ content of DNA: 66.5 to $68.0 \mathrm{~mol} \%$. There is high interstrain DNA homology.

Type strain: GA3 (= DSM 1034).

Source: Isolated from soil, mud, or water by liquid enrichment for hydrogen bacteria and by the use of a gas atmosphere consisting of $10 \%$ $\mathrm{O}_{2}, 10 \% \mathrm{CO}_{2}$, and $80 \% \mathrm{H}_{2}$.

The strains of $P$. pseudoflava differ from $P$. flava with respect to the characters listed in Table 8.

\section{ACKNOWLEDGMIENTS}

We are grateful to I. Probst, who made the cytochrome difference spectra, to $K$. Schmidt for assistance in the analysis of the pigments, to G. Remberg for performing mass spectroscopy, and to $J$. Wiegel for performing the polymyxin $B$ treatment. We thank $H$. J. Knackmuss for providing us with pure glycogen and R. Ansorg for introducing us to serology and for valuable discussions. We received generous help from $R$. Brinkmann. We are indebted to M. P. Starr for reading the manuscript.

\section{REPRINT REQUESTS}

Address reprint requests to: Prof. Dr. H. G. Schlegel, lnstitut für Mikrobiologie, Abteilung für Bakterienphysiologie der Universität Göttingen, Grisebachstr. 8, 3400 Göttingen, Federal Republic of Germany.

\section{LTERATURE CITED}

1. Andrewes, A. G., S. Herzberg, S. Liaaen-Jensen, and M. P. Starr. 1973. Xanthomonas pigments. 2. The Xanthomonas "carotenoids"-non-carotenoid, brominated aryl-polyene esters. Acta Chem. Scand. 27:2383-2395.

1a.Auling, G., F. Mayer, and H. G. Schlegel. 1977. Isolation and partial characterization of normal and defective bacteriophages for Pseudomonas pseudoflava. Arch. Microbiol. 115:237-248.

2. Bergmeyer, H. U. 1974. Methoden der enzymatischen Analyse. Verlag Chemie, Weinheim.

3. Cowan, S. T. 1974. Cowan and Steel's manual for the identification of medical bacteria, 2nd ed. Cambridge University Press, New York.

4. Davis, D. H., M. Doudoroff, R. Y. Stanier, and M. Mandel. 1969. Proposal to reject the genus Hydrogenomonas: taxonomic implications. Int. J. Syst. Bacteriol. 19:375-390.

5. Davis, D. H., R. Y. Stanier, M. Doudoroff, and M. Mandel. 1970. Taxonomic studies on some Gram-negative polarly flagellated "hydrogen bacteria" and related species. Arch. Mikrobiol. 70:1-13.

6. DeLey, J., H. Cattoir, and A. Reynaerts. 1970. The quantitative measurement of DNA-hybridization from renaturation rates. Eur. J. Biochem. 12:133-142. 
this date, been validly published, it is available for proposal as the name of either the same organism to which it was originally applied or a different organism. To prevent chaos and confusion, we prefer the former alternative. According to Provisional Rule B2 of the Bacteriological Code (13), we revive the name as follows: Streptomyces cavourensis sp. nov. (nom. rev.) (ca.vour.en' sis. M.L. adj. cavourensis of Cavour; named after Conte di Cavour, an Italian statesman and hero (1810-1861)). Thus the name $S$. cavourensis refers to the same organism to which Giolitti applied the name, but the name is to be attributed to the present authors, namely, Skarbek and Brady. The description of this species, based on four strains-829, Illinois 205-2 (= NRRL B-3001), Illinois 205-2M (= NRRL B-3002), and AUW-83-is as follows:

Streptomyces cavourensis sp. nov. (nom. rev.)

Spore chain morphology. Section Recti. flexibiles. Mature spore chains are generally flexuous and contain 10 to 50 or more spores per chain.

Spore surface. Smooth.

Color of colony. The aerial mass color on yeast-malt extract agar, oatmeal agar, inorganic salts-starch agar, and glycerol-asparagine agar is in the yellow or red $(3 \mathrm{ec})$ color series.

Reverse side of colony. No distinctive pigments are produced on the reverse sides of colonies other than yellow-brown on yeast-malt extract agar, oatmeal agar, inorganic salts-starch agar, and glycerol-asparagine agar.

Color in medium. Melanoid pigment production in peptone-yeast extract-iron agar and tryptone-yeast extract broth varies with the strain. No distinctive soluble pigments other than melanoid pigments are produced in yeastmalt extract agar, oatmeal agar, inorganic saltsstarch agar, and glycerol asparagine agar.

Carbon utilization. D-Glucose, D-xylose, Dfructose, and D-mannitol are utilized for growth. Growth varies with the strain from a trace amount of growth to good growth with L-arabinose. Growth does not occur with meso-inositol, D-raffinose, L-rhamnose, or D-sucrose.

Special characteristics. The kinds of antibiotics produced vary with the strain. Some strains produce the antifungal antibiotics flavensomycin and humidin; others produce the antibacterial, antitumor agent chromomycin $\mathrm{A}_{3}$ and other chromomycins.

Type strain. The type strain is 829 , isolated from farm soil, Italy (4). Cultures of this strain are available from several culture collections, among which are the American Type Culture Collection (under the number 14889), the Northern Regional Research Center, Peoria, Ill. (un- der the number 2740), and the Centraalbureau voor Schimmelcultures, Baarn, Netherlands (under the number 669.69).

Strain AUW-83 can be distinguished from the flavensomycin-producing strains of $S$. cavourensis-829, Illinois 205-2, and Illinois 205$2 \mathrm{M}$-primarily on the basis of its ability to produce a structurally unrelated antibiotic substance, chromomycin $\mathrm{A}_{3}$ (24). Chromomycin $\mathrm{A}_{3}$ is a glycoside antibiotic (molecular weight 1,183 ) which contains no nitrogen; its structural formula is $\mathrm{C}_{57} \mathrm{H}_{82} \mathrm{O}_{26}$. Its biological spectrum includes antagonism of the growth of gram-positive bacteria but not of gram-negative bacteria or of fungi. Although incomplete, the chemistry of flavensomycin has been reviewed by Gottlieb (8). Mass spectral analysis indicated it to have a molecular weight of 870 and an empirical formula of $\mathrm{C}_{47} \mathrm{H}_{67} \mathrm{NO}_{14}$. Flavensomycin is reported to be insecticidal and antifungal, with little or no antibacterial activity $(5,6)$. Xanthicin, the antibiotic produced by $S$. xanthochromogenes strain 689 , was found to be weakly active against certain fungi and gram-positive bacteria. The empirical formula $\mathrm{C}_{13} \mathrm{H}_{15} \mathrm{NO}_{5}$ was suggested for xanthicin (28). The chemical and biological data suggest that the chromomycins, flavensomycin, and xanthicin are structurally unrelated antibiotics.

Streptomycetes are generally susceptible to the antibiotics which they produce but usually at concentrations much higher than those found to inhibit other streptomycetes. Strain AUW-83 shows susceptibility to chromomycin $\mathrm{A}_{3}$ at a concentration of approximately $50 \mu \mathrm{g}$ per disk. The greater resistance displayed by strain AUW-83 or, contrarily, the greater susceptibility exhibited by strains 829 , Illinois $205-2$, and Illinois $205-2 \mathrm{M}$ to chromomycin $\mathrm{A}_{3}(1.0 \mu \mathrm{g}$ per disk) is probably an indication that the latter strains do not have the capacity to produce the chromomycin antibiotics. This contention is supported by the data in this report, which indicate that no activity suggestive of the presence of the chromomycins was detectable in the broths fermented by these strains.

Therefore, on the basis of a qualitative difference in antibiotic-producing capacity, strain AUW-83 is regarded as belonging to a distinct subspecies of Streptomyces cavourensis, for which the name Streptomyces cavourensis subsp. washingtonensis subsp. nov. (wash.ing.ton.en'sis. M.L. adj. washingtonensis pertaining to Washington State, where strain AUW-83 was isolated) is proposed. It differs from the type subspecies in that it produces the antibacterial, antitumor antibiotic chromomycin $A_{3}$ and other chromomycins. The type strain of S. cavourensis subsp. washingtonensis is strain 
AUW-83, a culture of which has been deposited with the American Type Culture Collection under the number 27732 and at the Northern Regional Research Center, Peoria, Ill., under the number B-8030.

\section{ACKNOWLEDGMENTS}

J. D. Skarbek gratefully acknowledges Public Health Service Graduate Fellowships from the National Institute of General Medical Sciences (no. 5-F01-GM-43,302) for the years 1969 to 1973. The authors thank J. D. Mauseth and the Department of Botany, The University of Washington, for electron micrographs and photomicrographs; Robert Nauman, School of Dentistry, The University of Maryland at Baltimore, for electron microscope examinations; E. B. Shirling, Ohio Wesleyan University, Delaware, Ohio, for the loan of a set of the Tresner-Backus color guides; V. B. D. Skerman, P. H. A. Sneath, and S. P. Lapage for their nomenclatural advice; and T. G. Pridham for cultures of strains Illinois 205-2 and Illinois 205-2M

\section{REPRINT REQUESTS}

Address reprint requests to: Dr. Jerry D. Skarbek, School of Pharmacy, University of Maryland, 636 West Lombard St., Baltimore, MD 21201.

\section{LITERATURE CITED}

1. Arishima, M., J. Sakamoto, and T. Sato. 1956. Studies on an antibiotic Streptomyces no. 689 strain. I. Taxonomic studies. J. Agric. Chem. Soc. Japan 30:469-471.

2. Berlin, Y. A., O. A. Kiseleva, M. N. Kolosov, M. M. Shemyakin, V. S. Soifer, I. V. Vasina, I. V. Yartseva, and V. D. Kurnetsov. 1968. Aureolic acid group of antitumor antibiotics. Nature (London) 218:193194.

3. Buchanan, R. E., J. G. Holt, and E. F. Lessel, Jr. 1966. Index Bergeyana: an annotated alphabetical listing of names of the taxa of the bacteria, p. 1098. Williams and Wilkins Co., Baltimore.

4. Centraalbureau voor Schimmelcultures. 1972. List of cultures. Institute of the Royal Netherlands Academy of Sciences and Letters, Baarn, The Netherlands.

5. Chacko, C. I., and D. Gottlieb. 1965. The isolation of flavensomycin and humidin from the same strain of Streptomyces griseus and their antimicrobial properties. Phytopathology 55:587-591.

6. Craveri, R., and G. Giolitti. 1957. An antibiotic with fungicidal and insecticidal activity produced by Streptomyces. Nature (London) 179:1307.

7. Giolitti, G. 1958. Studies on two strains of Streptomyces producers of flavensomycin, an antibiotic with fungicidal and insecticidal activity, p. 382-383. In G. Tunevall (ed.), Abstracts of the VII International Congress of Microbiology, Abstract 22k. Almqvist and Wiksells, Uppsala, Sweden.

8. Gottlieb, D. 1967. Flavensomycin, p. 617-620. In D. Gottlieb and P. D. Shaw (ed.), Antibiotics, vol. 1. Springer-Verlag, New York.

9. Gottlieb, D., and E. B. Shirling. 1970. An analysis of species groups among Streptomyces, p. 67-77. In $\mathrm{H}$. Prauser (ed.), The Actinomycetales. VEB Gustav Fischer, Jena.

10. Hütter, R. 1967. Systematik der streptomyceten unter besonderer berücksichtigung der von ihnen gebildeten antibiotica. S. Karger, Basel

11. Kelly, D. L., and D. B. Judd. 1955. The ISCC-NBS method of designating colors and a dictionary of color names. U. S. Department of Commerce Circular 553. U. S. Government Printing Office, Washington, D. C. 12. Kovach, J. S., C. G. Moertel, D. L. Ahmann, R. G. Hahn, A. J. Sehutt, and J. V. Donadio, Jr. 1973 Phase I study of chromomycin $\mathrm{A}_{3}$ (NSC-58514). Cancer Chemother. Rep. 57:341-347.

13. Lapage, S. P., P. H. A. Sneath, E. F. Lessel, V. B. D. Skerman, H. P. R. Seeliger, and W. A. Clark (ed.). 1975. International code of nomenclature of bacteria and statutes of the International Committee on Systematic Bacteriology and statutes of the Bacteriology Section of the International Association of Microbiological Societies. American Society for Microbiology, Washington, D. C.

14. Lyons, A. J., and T. G. Pridham. 1973. Standard antimicrobial spectra as aids in characterization and identification of Actinomycetales, p. 205-211. In E. D. Murray (ed.), Developments in industrial microbiology. American Institute of Biological Sciences, Washington, D. C.

15. Moertel, C. G., A. J. Schutt, R. G. Hahn, T. A. Marciniak, and R. J. Reitemeier. 1975. Phase II study of chromomycin $\mathrm{A}_{3}$ (NSC-58514) in advanced colorectal carcinoma. Cancer Chemother. Rep. 59:577-579.

16. National Committee for Clinical Laboratory Standards. 1975. Performance standards for antimicrobial disc susceptibility tests. Villanova, $\mathrm{Pa}$.

17. Pridham, T. G. 1964. Taxonomic studies of Streptomyces griseus (Krainsky) Waksman et Henrici: a species comprising many subspecies, p. 104-115. Antimicrob. Agents Chemother. 1963.

18. Pridham, T. G., and H. D. Tresner. 1974. Family Streptomycetaceae and the genus Streptomyces, p. 747-829. In R. E. Buchanan and N. E. Gibbons (ed.), Bergey's manual of determinative bacteriology, 8 th ed. Williams and Wilkins Co., Baltimore.

19. Shirling, E. B., and D. Gottlieb. 1966. Methods for characterization of Streptomyces species. Int. J. Syst. Bacteriol. 16:313-340.

20. Shirling, E. B., and D. Gottlieb. 1968. Cooperative description of type cultures of Streptomyces. II. Species descriptions from first study. Int. J. Syst. Bacteriol. 18:69-189.

21. Shirling, E. B., and D. Gottlieb. 1968. Cooperative description of type cultures of Streptomyces. III. Additional species descriptions from first and second studies. Int. J. Syst. Bacteriol. 18:279-392.

22. Shirling, E. B., and D. Gottlieb. 1969. Cooperative description of type cultures of Streptomyces. IV. Species descriptions from the second, third, and fourth studies. Int. J. Syst. Bacteriol. 19:391-512.

23. Shirling, E. B., and D. Gottlieb. 1972. Cooperative description of type strains of Streptomyces. V. Additional descriptions. Int. J. Syst. Bacteriol. 22:265-394.

24. Skarbek, J. D., and L. R. Brady. 1975. Isolation of chromomycin $\mathbf{A}_{3}$ from a new subspecies of Streptomyces. Lloydia 38:369-377.

25. Skarbek, J. D., and L. R. Brady. 1978. Preliminary taxonomic study of members of the order Actinomycetales that produce antibiotics of the aureolic acid group. Int. J. Syst. Bacteriol. 28:54-66.

26. Waksman, S. A. 1959. The actinomycetes, vol. 1, p. 138-147. The Williams and Wilkins Co., Baltimore.

27. Waksman, S. A. 1961. The actinomycetes, vol. 2. The Williams and Wilkins Co., Baltimore.

28. Waksman, S. A., and H. A. Lechevalier. 1962. The actinomycetes, vol. 3. The Williams and Wilkins Co., Baltimore.

29. Wayne, L. G., W. J. Juarez, and E. G. Nichols. 1958. Arylsulfatase activity of aerobic Actinomycetales. J. Bacteriol. 75:367-368. 